\title{
Carbon source utilization and hydrogen production by isolated anaerobic bacteria
}

\author{
R. Jame, V. Zelená, B. Lakatoš, L'. Varečka \\ Institute of Biochemistry and Microbiology, Faculty of Chemical and Food Technology, \\ Slovak University of Technology, Radlinského 9, Bratislava 812 37, Slovakia \\ ludovit.varecka@stuba.sk
}

\begin{abstract}
Five bacterial isolates were tested for their ability to generate hydrogen during anaerobic fermentation with various carbon sources. One isolate from sheep rumen was identified as Escherichia coli and four isolates belonged to Clostridium spp. Glucose, arabinose, ribose, xylose, lactose and cellobiose were used as carbon sources. Results showed that all bacterial strains could utilize these compounds, although the utilization of pentoses diminished growth yield. The excretion of monocarboxylic acids (acetate, propionate, formiate, butyrate) into medium was changed after replacing glucose by other carbon sources. Di- and tricarboxylic acids were excreted in negligible amounts only. Spectra of excreted carboxylic acids were unique for each strain and all carbon sources. All isolates produced $\mathrm{H}_{2}$ between $4-9 \mathrm{mmol} \cdot \mathrm{L}^{-1}$ during the stationary phase of growth with glucose as energy source. This value was dramatically reduced when pentoses were used as carbon source. Lactose and cellobiose, starch and cellulose were suitable substrates for the $\mathrm{H}_{2}$ production in some but not all isolates. $\mathrm{No}_{2}$ was produced by proteinaceous substrate, such as blood. Results show that both substrate utilization and physiological responses (growth, excretion of carboxylates, $\mathrm{H}_{2}$ production) are unique functions of each isolate.
\end{abstract}

Keywords: Clostridium sp., glucose, monosaccharides, disaccharides, hydrogen

\section{Introduction}

The formation of hydrogen gas during anaerobic fermentation was intensively studied during last two decades. This resulted in accumulation of a large body of information concerning both production of biohydrogen and its microbiological background, which has been reviewed recently by several authors (Chandrasekhar et al., 2015; Patel and Kalia, 2013; Rittmann and Herwig, 2012; Hung et al., 2011; Ntaikou et al., 2010; Nath and Das, 2004; Hallenbeck and Benemann, 2002).

Most microbial models used for the dark hydrogen fermentation belong to three bacterial families - Clostridiaceae, Thermoanaerobacterales and Enterobacteriaceae (Rittmann and Herwig, 2012), although novel strains belonging to Bacteroidetes and Actinomycetales were found to produce hydrogen during anaerobic fermentation (Xing et al., 2008; Hung et al., 2011). Nevertheless, most strains used for studies of biohydrogen production belong to Clostridium spp, although some studies used undefined consortia (Rajhi et al., 2013; Boboescu et al., 2014; Sivagurunathan et al., 2014) or co-cultures of two or more microorganisms (Beckers et al., 2010; Masset et al., 2012; Romão et al., 2014; Chen et al., 2015). Various Clostridium species became enriched during the cultivation of mixed cultures with complex substrates (Boboescu et al., 2014; Sivagurunathan et al., 2014; Yin and Yang, 2016). These may be crucial for the overall hydrogen production rather than the original mixed cultures (Hiligsmann et al., 2011).

Clostridia are known to grow on both polysaccharidic and proteinaceous substrates, and possess necessary hydrolytic enzymes, such as cellulases (Demain et al., 2005), xylanases (Thomas et al., 2014), amylases (Shih and Labbé, 1995), or proteases (Janoir et al., 2004). Nevertheless, some differences in the utilization of carbonaceous substrates among the used clostridial strains could be observed (Beckers et al., 2010).

The goal of this work was to find out the optimal carbon sources for the hydrogen production in the group of novel Clostridium and Escherichia coli isolates. These strains were obtained as by-products of the isolation of anaerobic fungi from cow and sheep rumens and from the activated sludge (Zelená et al., 2016). After their ITS typing, several bacterial isolates were screened for the hydrogen production in the standard RCM medium. The best hydrogen producers are those presented in this work.

\section{Materials and Methods}

\section{Bacterial strains}

Five bacterial isolates were used, which were described previously (Jame et al., 2011). Briefly, these isolates were characterized by the sequencing of ITS fragments, and were identified as Escherichia coli DH1 (ME8569) (No 2-24) (isolated from the sheep rumen) with $98 \%$ similarity in the BLAST query, and 
four strains isolated from the activated sludge, which belonged to Clostridia with some similarity to known species. These are: Clostridium botulinum E3, strain Alaska 43 (82\% similarity) (referred to as AK-1-4), Clostridium difficile M69 (93\% similarity) (AK-1-5), Clostridium perfringens clone CVCC90.WE (99 \% similarity) (AK 1-9), and Clostridium spp. (99\% similarity) (AK 1-12). All bacterial strains were propagated on the reinforced clostridial medium (RCM).

Bacteria were cultivated in anaerobic cultivation chambers under the anaerobic atmosphere formed by BBL GasPack System (Becton Dickinson) at $37^{\circ} \mathrm{C}$. All operations were performed in the Bactron I anaerobic chamber (Sheldon Laboratories).

\section{Reinforced Clostridial Medium (RCM)}

Medium was done according to Kalil et al. (2009). Its composition was following: Glucose $5 \mathrm{~g} \cdot \mathrm{L}^{-1}$, Yeast extracts $13 \mathrm{~g} \cdot \mathrm{L}^{-1}$, L-Cysteine.HCl $1 \mathrm{~g} \cdot \mathrm{L}^{-1}$, agar $0.5 \mathrm{~g} \cdot \mathrm{L}^{-1}, \mathrm{pH} 6.8 \pm 0.2$. Other tested monoor disaccharides were added instead of glucose at concentration $5 \mathrm{~g} \cdot \mathrm{L}^{-1}$, starch or cellulose was added at concentrations $10 \mathrm{~g} \cdot \mathrm{L}^{-1}$ without other carbon source. UHT milk or heparinized blood was added at concentrations $15 \%(\mathrm{v} / \mathrm{v})$.

\section{Growth curve measurements with monosaccharides and polysaccharides as substrates}

Single bacterial culture was cultivated in $5 \mathrm{ml}$ media (such as RCM with glucose or other substrate) inoculated under anaerobic condition by bacterial species to have concentration of cells about $2 \times 10^{7} \mathrm{ml}^{-1}$, and incubated under anaerobic conditions at $37^{\circ} \mathrm{C}$ with rotation (IKA KS 40000 ic control) (181 rpm). Growth of bacteria was monitored by measurement of $\mathrm{A}_{550}$ (Biochrom colorimeter Libra 52, U.K.) at 0 hour, and after every $4^{\text {th }}$ hour until stationary phase was reached.

\section{Measurements of metabolic gases}

Tested samples were prepared from pure bacterial cultures in $40 \mathrm{ml}$ of liquid medium into $50 \mathrm{ml}$ flasks with stoppers with inlet and outlet tubings and placed in Micro-Oxymax (Columbus Instruments, Columbus, OH, U.S.A.) gas analyzer equipped with sensors for $\mathrm{O}_{2}, \mathrm{CO}, \mathrm{CO}_{2}, \mathrm{H}_{2} \mathrm{~S}$, $\mathrm{H}_{2}$ and $\mathrm{CH}_{4}$ from which traces of $\mathrm{O}_{2}$ were removed by flushing with pyrogallol-treated $\mathrm{N}_{2}$. Measurement started after the system was calibrated with calibration gases. Measurements were carried out at $37^{\circ} \mathrm{C}$.

\section{Measurement of organic acids by HPLC}

Organic acids were measured by isocratic HPLC with $9 \mathrm{mM} \mathrm{H}_{2} \mathrm{SO}_{4}$ as mobile phase on the Shimadzu HPLC system equipped with double wavelength UV-detector (214 and $254 \mathrm{~nm}$ ) a Watrex $300 \times 8 \mathrm{~mm}$ polymer IEX column in $\mathrm{H}^{+}$form. Twenty $\mu \mathrm{L}$ of cultivation media obtained by centrifugation and pre-filtered through the $0.22 \mu \mathrm{m}$ membrane was applied on the column. Chromatography was performed at $41^{\circ} \mathrm{C}$. The system was calibrated by series of standard organic acids.

\section{Results}

Growth of microorganisms on saccharidic substrates In the first instance, the ability of isolated strains to utilize other substrates besides glucose was tested. These included pentoses arabinose, ribose and xylose, and disaccharides cellobiose and lactose. It was found that all strains could grow in media with these substrates to some extent displaying a typical growth curve. Results of these experiments are summarized in the Table 1. Their most conspicuous feature is that all strains had different preferences to carbon sources other than glucose, although

Tab. 1. Growth of tested bacterial strains cultivated with selected mono- and disaccharides as sole carbon sources.

\begin{tabular}{lccccc}
\hline $\begin{array}{l}\text { Relative growth } \\
\text { compared to growth } \\
\text { on glucose as carbon }\end{array}$ & $\begin{array}{c}\text { Escherichia coli } \\
\text { source in RCM (\%) }\end{array}$ & $\begin{array}{c}\text { Clostridium spp. } \\
\text { (AK 1-12) }\end{array}$ & $\begin{array}{c}\text { Clostridium } \\
\text { perfringens } \\
\text { (AK 1-9) }\end{array}$ & $\begin{array}{c}\text { Clostridium } \\
\text { difficile } \\
(\text { AK 1-5) }\end{array}$ & $\begin{array}{c}{ }^{*} \text { C.botulinum sp. } \\
\text { (AK 1-4) }\end{array}$ \\
\hline Glucose & $100(1.18)$ & $100(1.28)$ & $100(1.22)$ & $100(1.42)$ & $100(1.25)$ \\
Arabinose & 33.5 & 24.2 & 12.7 & 28.5 & 18.2 \\
Ribose & 56.9 & 90.0 & 39.3 & 39.1 & 57.4 \\
Xylose & 70.0 & 99.8 & 62.5 & 61.9 & 69.4 \\
Lactose & 91.0 & 138.1 & 90.8 & 81.0 & 92.0 \\
Cellobiose & 105.1 & 169.8 & 103.6 & 63.5 & 106.1 \\
\hline
\end{tabular}

Results are expressed as \% of growth on glucose at time of maximal optical density for each micro-organism. $\mathrm{A}_{550}$ after $16 \mathrm{~h}$ of cultivation is shown in parentheses.

*Clostridium that have some similarity with Clostridium botulinum. 
almost identical growth curves were obtained if glucose was used as the sole carbon source (Table $\mathrm{I}^{-} \mathrm{A}_{550}$ after $16 \mathrm{~h}$ cultivation). The least effective carbon source was arabinose, which yielded the concentration of cells, which varied from 12 to $33 \%$ of this obtained with glucose. Ribose and xylose were better carbon sources with the efficiency varying between of $60-70 \%$ of glucose. However, the isolate AK 1-12 utilized these pentoses with the efficiency approaching this of glucose. The utilization of disaccharides also varied between isolates. Lactose was a slightly (by 10-20\%) less efficient carbon source in all isolates but AK 1-12. Cellobiose was utilized with a better cellular yield than glucose (except AK 1-5) suggesting that all strain have en- zymic capacity for the hydrolysis of cellobiose but this capacity may be limiting in AK 1-5 strain.

\section{Excretion of carboxylic acids}

Metabolic activity of microorganisms is intimately connected with the excretion of organic acids. Also, our strains of Clostridium and E. coli isolate produced organic acids, and excreted them into cultivation medium. Results of these analyses are shown in the Table 2. The major excreted metabolite was found to be acetic acid followed by formic acid, propionic acid, whereby butyric acid, a metabolite of butanol fermentative pathway was excreted in some isolates and some carbon sources only. Tricarboxylic cycle intermediates were excreted only

Tab. 2. Production of carboxylic acids by tested bacterial strains cultivated with selected mono- and disaccharides as sole carbon sources.

\begin{tabular}{|c|c|c|c|c|c|c|c|c|c|c|}
\hline Strain & Carbon source & Form & Mal & Citr & $\alpha-K G$ & Acet & Prop & But & Fum & Succ \\
\hline \multirow{6}{*}{$\begin{array}{l}\text { Escherichia coli } \\
\text { (No. 2-24) }\end{array}$} & Glc & N.D. & 10.2 & 0.61 & 61.1 & 458.7 & 244.5 & N.D. & 8.1 & N.D. \\
\hline & Ara & 200.0 & 8.1 & N.D. & 66.8 & 334.4 & 209.1 & N.D. & N.D. & N.D. \\
\hline & Rib & 6.4 & 1.1 & 21.8 & N.D. & 745.6 & 122.4 & N.D. & N.D. & N.D. \\
\hline & Xyl & N.D. & 90.6 & N.D. & 7.5 & 954.6 & 154.1 & N.D. & N.D. & 5 \\
\hline & $\mathrm{Lac}$ & N.D. & 8.1 & N.D. & 9.3 & 474.9 & 115.6 & 115.6 & 11.7 & N.D. \\
\hline & Cel & N.D. & 3.1 . & N.D. & N.D. & 346.7 & N.D. & N.D. & N.D. & 254.3 \\
\hline \multirow{6}{*}{$\begin{array}{l}\text { Clostridium spp. } \\
\text { (AK 1-12) }\end{array}$} & Glc & 117.4 & 46.8 & N.D. & 2.9 & 231.7 & 231.7 & 148.0 & N.D. & N.D. \\
\hline & Ara & 14.8 & 19.9 & 10.2 & N.D. & 50.1 & 57.0 & 81.8 & N.D. & 32.6 \\
\hline & Rib & 28.7 & 47.0 & 10.2 & N.D. & 206.9 & 143.0 & 146.1 & N.D. & 32.6 \\
\hline & $\mathrm{Xyl}$ & 79.2 & 54.9 & 3.3 & 1.9 & 259.9 & 131.0 & N.D. & N.D. & 19.8 \\
\hline & $\mathrm{Lac}$ & 170.6 & 7.5 & 0.8 & 8.8 & 297.1 & 172.2 & N.D. & N.D. & N.D. \\
\hline & Cel & 163.4 & 5.1 & N.D. & 6.6 & 394.9 & 144.2 & 941.0 & N.D. & 585.3 \\
\hline \multirow{6}{*}{$\begin{array}{l}\text { Clostridium } \\
\text { perfringens } \\
\text { (AK 1-9) }\end{array}$} & Glc & 109.6 & 89.3 & 2.3 & N.D. & 285.3 & 63.9 & 104.0 & N.D. & N.D. \\
\hline & Ara & 13.4 & 13.4 & N.D. & N.D. & 114.9 & 63.8 & 132.1 & 12.9 & 28.5 \\
\hline & Rib & N.D. & 744.8 & 2.7 & N.D. & 248.2 & 39.7 & 179.0 & 10.1 & 14.5 \\
\hline & Xyl & N.D. & 43.3 & N.D. & 74.4 & 305.7 & 43.5 & 319.8 & 9.9 & 36.3 \\
\hline & $\mathrm{Lac}$ & 53.7 & 2.4 & N.D. & 2.9 & 495.1 & 48.3 & N.D. & N.D. & 12.1 \\
\hline & Cel & 159.7 & 4.3 & N.D. & 2.0 & 697.4 & 45.7 & N.D. & N.D. & 5.7 \\
\hline \multirow{6}{*}{$\begin{array}{l}\text { Clostridium difficile } \\
\text { (AK 1-5) }\end{array}$} & Glc & 18.4 & 2.6 & N.D. & 1.0 & 405.6 & N.D. & N.D. & 7.0 & N.D. \\
\hline & Ara & N.D. & 28.0 & N.D. & 1.9 & 463.7 & N.D. & N.D. & 12.3 & 48.9 \\
\hline & Rib & N.D. & 40.3 & N.D. & 0.97 & 479.5 & 82.0 & N.D. & 11.3 & 11.8 \\
\hline & Xyl & N.D. & 43.2 & N.D. & 2.4 & 668.3 & N.D. & N.D. & N.D. & 21.3 \\
\hline & $\mathrm{Lac}$ & N.D. & 2.7 & N.D. & 4.3 & 351.6 & 129.4 & N.D. & N.D. & N.D. \\
\hline & Cel & 0.68 & 3.2 & N.D. & 0.77 & 132.6 & 51.9 & N.D. & N.D. & N.D. \\
\hline \multirow{6}{*}{$\begin{array}{l}\text { similar } \\
\text { to Clostridium } \\
\text { botulinum } \\
\text { (AK 1-4) }\end{array}$} & Glc & 133.1 & 14.6 & N.D. & 3.9 & 229.2 & 76.2 & 223.4 & N.D. & N.D. \\
\hline & Ara & 240.9 & 44.8 & N.D. & N.D. & 119.2 & 210.5 & 131.1 & 10.0 & N.D. \\
\hline & Rib & 90.2 & 76.6 & N.D. & 1.1 & 340.0 & 116.3 & 380.2 & 4.1 & 0.49 \\
\hline & Xyl & 138.2 & 90.7 & N.D. & 2.5 & 349.6 & 121.6 & 404.1 & 0.72 & 16.5 \\
\hline & $\mathrm{Lac}$ & 259.6 & 5.8 & N.D. & 6.8 & 316.6 & 122.5 & 508.0 & 6.8 & N.D. \\
\hline & Cel & 218.3 & 12.5 & N.D. & 66.3 & 435.7 & 115.6 & 115.6 & 11.7 & N.D. \\
\hline
\end{tabular}

Concentrations of carboxylic acids in the cultivation medium $\left(\mu \mathrm{mol} \cdot \mathrm{L}^{-1}\right)$ were measured by HPLC as described in Material and Methods. Abbreviations: Glc - glucose, Ara - arabinose, Rib - ribose, Xyl - xylose, Lac - lactose, Cel - cellobiose, Form - formiate, Mal - malate, Citr - citrate, $\alpha$-KG - $\alpha$-Ketoglutarate, Acet - acetate, Prop - propionate, But - butyrate, Fum - fumarate, Succ - succinate. N.D. - no carboxylate detected. 
in minute amounts, which were about one order of magnitude less than those of monocarboxylic acids, or, mostly, they were not excreted at all. As expected, the substitution of glucose by pentoses or disaccharides had an impact on the excretion of organic acids but simple conclusions cannot be drawn. For example, arabinose (the least efficient carbon source) decreased the production in three of five strains and in two strains the production was stimulated. Similar differences could be found for all other carbon sources. Also, differences between bacterial strains were observed. The comparison of excretion patterns shows that the responses of tested strain are rather unique than universal.

\section{Total hydrogen production by bacteria growing with various carbon sources.}

In other experiments, the production of hydrogen was measured under identical conditions. The results are shown in the Table 3 . All tested bacteria produced $\mathrm{H}_{2}$ when cultivated with glucose, lactose or cellobiose. When pentoses (arabinose, xylose, ribose) were used as sole carbon sources, $\mathrm{H}_{2}$ production was generally lower and some differences were seen between individual isolates. Isolate AK 1-12 failed to produce $\mathrm{H}_{2}$ on all pentoses, and its capacity to produce $\mathrm{H}_{2}$ was the lowest of all tested isolates, but the lower $\mathrm{H}_{2}$ production by pentoses was observed in all Clostridium isolates and E. coli isolate. Polysaccharidic carbon sources (soluble starch and microcrystalline cellulose) were less efficient carbon sources as compared with monosaccharides and dramatic differences between individual strains were observed. This indicates that the activities of pertinent hydrolases may be limiting for growth of cells on these substrates. Only the strain AK 1-5 produced hydrogen using all tested substrates.

In some experiments we measured also proteinaceous substrates for the production of $\mathrm{H}_{2}$, such as animal blood and milk. Only milk was found to be a moderately good substrate for the $\mathrm{H}_{2}$ production, while no $\mathrm{H}_{2}$ was produced with blood as substrate. This suggests that it is lactose, which is a utilized substrate in milk, and that the use of proteins as energy donors, described in Clostridium $s p p$. (Stickland reaction) may be limited by the low metabolic flow, or enzymes for Stickland reaction are absent in our isolates.

\section{Discussion}

In order to understand the metabolic versatility of isolates, the growth of those carbon sources was measured, which may occur in lignocellulosic materials (cellulose, starch) or their hydrolysates (glucose, xylose, arabinose, cellobiose). The isolates were able to utilize these compounds as substrates for supporting growth, although with the different efficiency. As expected, arabinose was the least efficient substrate, which may be explained by the necessity of its multi-step conversion to an intermediate of pentose phosphate pathway (Seiboth and Metz, 2011). Xylose and ribose were better substrates than arabinose. However, their efficiency as substrates reached that of glucose only in one strain (AK 1-12). It is feasible that this is the consequence of lower activities of enzymes converting these pentoses to intermediates of pentose phosphate pathway, too. Disaccharide metabolism may be affected by the low activity of corresponding hydro-

Tab. 3. Production of hydrogen gas by tested strains cultivated with selected mono- di-saccharides and poly-saccharides as sole carbon sources.

\begin{tabular}{lccccc}
\hline $\begin{array}{l}\text { Maximal } \mathrm{H}_{2} \text { concentration }(\mu \mathrm{mol} / \mathrm{l}) \\
\text { obtained upon cultivation in } \mathrm{RCM} \\
\text { with carbon sources shown below }\end{array}$ & $\begin{array}{c}\text { Escherichia } \\
\text { coli } \\
(\mathrm{No.} 2-24)\end{array}$ & $\begin{array}{c}\text { Clostridium } \\
\text { spp. } \\
(\text { AK 1-12) }\end{array}$ & $\begin{array}{c}\text { Clostridium } \\
\text { perfringens } \\
(\text { AK 1-9) }\end{array}$ & $\begin{array}{c}\text { Clostridium } \\
\text { difficile } \\
(\text { AK 1-5) }\end{array}$ & $\begin{array}{c}{ }^{*} \text { Clostridium } \\
\text { botulinum sp. } \\
(\text { AK 1-4) }\end{array}$ \\
\hline Glucose & 9029 & 4070 & 9378 & 7433 & 5018 \\
Arabinose & 2.5 & 5 & 2180 & 1558 & 477.5 \\
Ribose & 90 & 2.5 & 5443 & 3758 & 790 \\
Xylose & 112.5 & 3 & 6810 & 6230 & 25 \\
Lactose & 5296 & 116.6 & 8794 & 1143 & 7397 \\
Cellobiose & $\sim 9000$ & 7860 & 6183 & 8202.5 .1 & 8370 \\
Starch & 145 & 2.9 & 282. & 7613 & 592.5 \\
Cellulose & N.D. & 2.8 & N.D. & 6250 & 252.5 \\
Sheep blood & 603.0 & 0.03 & 0.05 & 0.05 & 16.0 \\
Milk & 3140 & N.D. & 1968 & 3554 & 2588 \\
\hline
\end{tabular}

*Clostridium that have some similarity with Clostridium botulinum.

N.D. - no $\mathrm{H}_{2}$ detected. 
lases in the strain AK1-5. Other isolates grew on both lactose and cellobiose almost similarly as on glucose.

The excretion of organic acids may mirror metabolic processes during the cultivation. The excretion of formiate reflect the activity of pyruvate-formiate lyase and leads to the formation of acetate. Both compounds were major metabolites excreted by our isolates except No 2-24 (E. coli) and AK 1-5 (similar to $C$. difficile) with glucose as carbon source. Pentoses suppressed the excretion of formiate probably due to the fact that the glycolytic pathway is not involved in their degradation. The absence of formiate in AK 1-5 isolate suggests some dramatic difference in the central carbon metabolism compared to other isolates and known data about clostridial metabolism. Other striking features are the lack of the butyrate excretion (except AK 1-4), the absence of lactate in all isolates, and the negligible excretion of dicarboxylates. These features may result either from intrinsic properties of isolates, or, as suggested by data of Collet et al. (2006), from the experimental setup we used in our experiments

The production of hydrogen was also strongly variable between isolates and was also affected by the carbon source. The most versatile producer seems to be the AK 1-5 strain. This strain did not produce formiate nor butyrate. It is possible that only this strain possess formate hydrogenlyase, which converts formiate carbon to hydrogen and carbon dioxide. This strain grows moderately on all substrates we tested suggesting that it contains all hydrolytic enzymes, although some other isolates may have higher activities of these enzymes. On the other hand, the production of hydrogen by other isolates may be limited by cellulase and amylase activities, or by the metabolism of minor substrates, such as pentoses. Thus, the single hydrogen producer may have a better application potential than several co-cultured microorganisms (Hiligsmann et al., 2011), if it possesses all necessary enzymic activities and metabolic pathways.

\section{Conclusion}

Five bacterial isolates from rumen and from activated sludge, which were identified as E. coli and Clostridium $s p p$., respectively, utilize a variety of saccharidic substrates with concomitant production of hydrogen and excretion of carboxylic acids. A strong variability in both excretion of organic acids and hydrogen production was observed among the tested strains. Only one isolate was found to grow and effectively produce hydrogen with all tested substrates. It appears that a consortium of several clostridia would be of advantage for the future experiments with the hydrogen production only if it is composed of strains which could complement their properties. Results stress the necessity to develop optimalization method for isolation of biotechnologically relevant isolates.

\section{Acknowledgement}

This work was supported by the Science and Technology Assistance Agency under the contracts of EU supported grant ITMS 26240120016.

\section{References}

Beckers L, Hiligsmann S, Hamilton C, Masset J, Thonart P (2010) Base 14, ISSN 1370-6233 numéro spécial 2.

Boboescu IZ, Ilie M, Gherman VD, Mirel I, Pap B, Negrea A, Kondorosi E, Bíró T, Maróti G (2014) Biotechnol Biofuels 7: 139. doi: 10.1186/s13068-014-0139-1. eCollection 2014.

Chandrasekhar K, Lee Y-J, Lee D-W (2015) Int. J. Mol. Sci. 16: 8266-8293. doi:10.3390/ijms 16048266.

Chen P, Wang Y, Yan L, Wang Y, Li S, Yan X, Wang N, Liang N, Li H (2015) Biol. Res. 6: 48. doi: 10.1186/ s40659-015-0015-x.

Collet C, Girbal L, Péringer P, Schwitzguébel J-P, Soucaille P (2006) Arch. Microbiol. 185: 331-339.

Demain AL, Newcomb M, Wu JHD (2005) Microbiol. Mol. Biol. Rev. 69: 124-154. doi:10.1128/MMBR.69.1.124154.2005.

Hallenbeck PC, Benemann JR (2002) Int. J. Hydrogen Energy 27: 1185-1193.

Hiligsmann S, Masset J, Hamilton C, Beckers L, Thonart P (2011) Bioresource Technol. 102: 3810-3818. doi: 10.1016/j.biortech.2010.11.094.

Hung C-H, Yi-T C, Yu-J C (2011) Bioresource Technol. 102: 8437-8444.

Jame R, Vilímová V, Lakatoš B, Varečka L' (2011) Hydrogen production by anaerobic bacteria grown on glucose and glycerol. Acta Chimica Slovaca 4: 145-157.

Janoir C, Grénery J, Savariau-Lacomme MP, Collignon A (2004) Pathol Biol (Paris) 52: 444-449.

Kalil MS, Alshiyab HSS, Yusoff WMW (2009) Am. J. Appl. Sci. 6: 1158-1168.

Masset J, Calusinska M, Hamilton C, Hiligsmann S, Joris B, Wilmotte A, Thonart P (2012) Biotechnol. Biofuels 5: 35. DOI: 10.1186/1754-6834-5-35.

Nath K, Das D (2004) Appl Microbiol Biotechnol 65: 520-529.

Ntaikou I, Antonopoulou G, Lyberatos G (2010) Waste Biomass Valor. 1: 21-39. DOI 10.1007/s12649-0099001-2.

Patel SK, Kalia VC (2013) Indian J. Microbiol. 53: 3-10. doi: 10.1007/s12088-012-0287-6.

Rajhi H, Díaz EE, Rojas P, Sanz JL (2013) Curr. Microbiol. 67: 30-355. doi: 10.1007/s00284-013-0328-3.

Rittmann S, Herwig C (2012) Microbial Cell Factories 11, $115-134$.

Romão BB, Batista FRX, Ferreira JS, Costa HCB, Resende MM, Cardoso VL (2014) Appl. Biochem. Biotechnol. 172: 3670-3685. 
Seiboth B, Metz B (2011) Appl. Microbiol. Biotechnol. 89: 1665-1673. doi: 10.1007/s00253-010-3071-8.

Shih NJ, Labbé RG (1995) Appl. Environ. Microbiol. 61: $1776-1779$

Sivagurunathan P, Sen B, Lin CY (2014) J. Biosci. Bioeng. 117: 222-228. doi: 10.1016/j.jbiosc.2013.07.015.

Thomas L, Joseph A, Gottumukkala LD (2014) Bioresource Technol. 158: 343-350. doi: 10.1016/j. biortech.2014.01.140.
Xing D, Ren N, Rittmann BE (2008) Appl. Environ. Microbiol. 74, 1232-1239.

Yin Y, Wang J (2016) Bioresour. Technol. 200: 217-222. doi: 10.1016/j.biortech.2015.10.027.

Zelená V, Birošová L, Olejníková P, Polák M, Lakatoš B, Varečka L' (2016) Gen. Physiol. Biophys. 35: 95-107. doi: 10.4149/gpb_2015036. 